\title{
THE VALUE OF LABORATORY TESTS IN HYPOTHERMIA
}

\author{
BY \\ PETER I. REED* AND KETTY E. GAVRILESCU \\ From the Departments of Neurosurgery and Pathology, Maida Vale Hospital, London
}

(RECEIVED FOR PUBLICATION NOVEMBER 26, 1957)

The biochemical changes which have been reported during and after hypothermia for cardiac surgery, and on which the literature is now considerable, are similar in man to those already found in animals. However, there are comparatively few references in the literature to investigations carried out in neurosurgical units, those of Gunton, Scott, Lougheed, and Botterell (1956) and Gray (1957) being the more comprehensive. The aim of the present investigation has therefore been to decide whether there are changes in the biochemistry in cranial as compared with cardiac surgery, what screening tests, if any, should be carried out in patients in whom hypothermia is indicated, and if any useful purpose is served by following up those cases with a view to anticipating any of the recognized or theoretical complications, to which reference will be made later.

\section{Method}

Investigations were carried out on 38 patients who were submitted to craniotomy, 34 for direct attack on intracranial vascular abnormalities and four for removal of a meningioma. The studies originally did not set out to be exhaustive and have thus not all been performed on the same number of cases. These have been compared with a control series of 10 patients who had undergone craniotomy without hypothermia, but in none of whom was there a vascular abnormality as all such cases were operated on under hypothermia. Venous blood samples were collected at normal body temperature before the operation, during hypothermia at about $27.5^{\circ} \mathrm{C}$. $\left(81.5^{\circ} \mathrm{F}.\right)$, and on the day after operation when normothermic conditions had once more been established. Twenty-four-hour urine collections were also made for cation estimations pre- and post-operatively. Serum sodium and potassium were estimated using a flame photometer (Domingo and Klyne, 1949), bicarbonate (Van Slyke and Cullen, 1917), calcium (Tisdall, 1923), urea, using Nessler's reagent, sugar (Folin and Wu, 1920), amylase (Somogyi, 1941), total protein by the specific gravity method, and fibrinogen (Hiller,

*Present address: Department of Medicine, Montreal General Hospital, Montreal, 25, Quebec, Canada.
McIntosh, and Van Slyke, 1927). Quick's one-stage method was used to estimate the prothrombin time, the clotting time was estimated by Dale and Laidlaw's (1911) shot method, and the platelet count was done by Lempert's modification of Kristenson's technique (Darmady and Davenport, 1954).

\section{Results}

Table I shows the average values found during the biochemical investigations in patients undergoing craniotomy with and without hypothermia. It will be seen that there was no alteration in the serum sodium level, though a few values outside normal limits were encountered. The changes in potassium were relatively small, and, although only once during and in four cases after hypothermia did the level drop below $3.9 \mathrm{mEq}$. $/ 1$., in comparison with cases where hypothermia was not used a significant difference was noted. The bicarbonate picture presented the greatest variations, there being a significant decrease, both during and after hypothermia, which was absent when this form of anaesthesia was not used. The concentration of calcium increased during hypothermia, returning to the pre-operative level subsequently. There was little difference in the 24hour urinary excretion of sodium and potassium with or without hypothermia. A few serum mag nesium studies were also carried out, but are as yet inconclusive and therefore being further pursued.

Significant changes were also noted in the levels of blood sugar and urea in patients under hypothermia. There was a consistent and marked increase in the sugar concentration during hypothermia with a marked post-hypothermic drop, though with an incomplete return to the preoperative level. The blood urea showed a steady rise during and after hypothermia, with values of up to $65 \mathrm{mg}$. per $100 \mathrm{ml}$. being recorded. The use of hypothermia also led to a small reduction in the total concentration of protein during and after operation with corresponding changes in the electrophoretic pattern. 
TABLE I

AVERAGE BIOCHEMICAL FINDINGS IN HYPOTHERMIA CASES

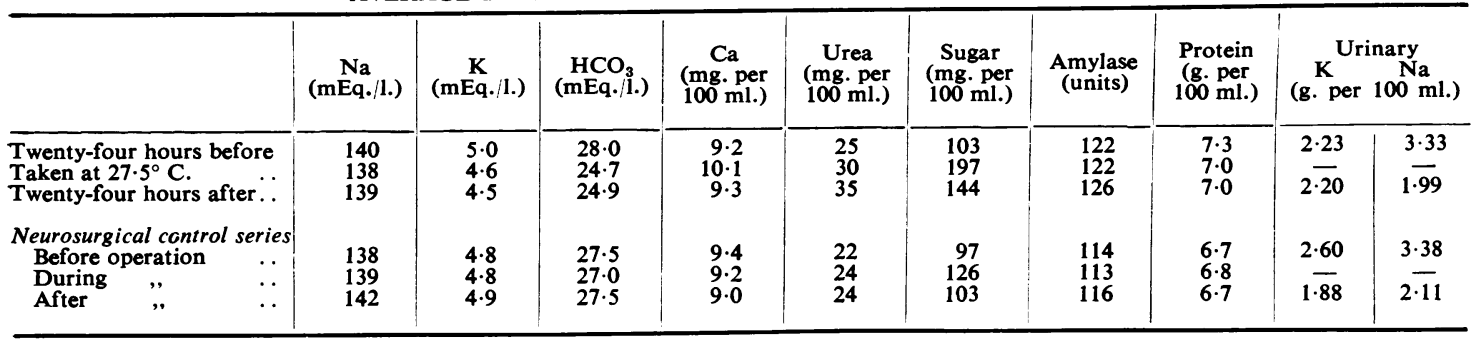

Table II shows the results in the investigation of the haematological picture. No significant changes could be demonstrated as resulting from the use of hypothermia.

TABLE II

AVERAGE HAEMATOLOGICAL FINDINGS IN HYPOTHERMIA CASES

\begin{tabular}{|c|c|c|c|c|}
\hline & $\begin{array}{c}\text { Pro- } \\
\text { thrombin } \\
\text { Con- } \\
\text { centration } \\
(\%)\end{array}$ & $\begin{array}{c}\text { Coagula- } \\
\text { tion } \\
\text { Time } \\
\text { (min.) }\end{array}$ & $\begin{array}{c}\text { Serum } \\
\text { Fibrino- } \\
\text { gen } \\
\text { (g. per } \\
100 \mathrm{ml} \text {.) }\end{array}$ & $\begin{array}{l}\text { Platelet } \\
\text { Count } \\
\text { (Thou- } \\
\text { sands) }\end{array}$ \\
\hline $\begin{array}{l}\text { Twenty-four hours } \\
\text { before } \\
\text { Taken at } 27 \cdot 5^{\circ} \text { C. . . } \\
\text { Twenty-four hours }\end{array}$ & $\begin{array}{l}97 \\
95\end{array}$ & $\begin{array}{l}3 \\
2\end{array}$ & $\begin{array}{l}0.31 \\
0.32\end{array}$ & $\begin{array}{l}235 \\
227\end{array}$ \\
\hline after $\quad . \quad \ldots$ & 91 & 3 & 0.32 & 227 \\
\hline $\begin{array}{c}\text { Neurosurgical con- } \\
\text { trol series } \\
\text { Before operation } \\
\text { During ", } \\
\text { After ", }\end{array}$ & $\begin{array}{l}95 \\
98 \\
80\end{array}$ & $\begin{array}{l}2 \frac{1}{2} \\
2 \\
3\end{array}$ & $\begin{array}{l}0 \cdot 33 \\
0.30 \\
0 \cdot 34\end{array}$ & $\begin{array}{l}220 \\
238 \\
240\end{array}$ \\
\hline
\end{tabular}

\section{Discussion}

It will be seen that with regard to the serum sodium and calcium levels, our findings are in accord with those of most workers, though Churchill-Davidson (1955) has observed a rise in plasma calcium levels only below $25^{\circ} \mathrm{C}$. $\left(77^{\circ}\right.$ F.). It is with the potassium and bicarbonate concentrations that one notes conflicting views. Brewin, Nashat, and Neil (1956) have noted during thoracotomy a metabolic acidosis due to an increase in lactic acid and accompanied by a corresponding reduction in bicarbonate. Deterling, Nelson, Bhonslay, and Howland (1955) and Stone, Donnelly, and Frobese (1956), on the other hand, have demonstrated a respiratory acidosis due to a reduction in respiratory activity at decreasing temperatures leading to $\mathrm{CO}_{2}$ retention and a fall in blood $p \mathrm{H}$. It has also been shown that hypothermia is accompanied by hypokalaemia (Swan, Zeavin, Holmes, and Montgomery, 1953 ; Jaulmes, Delga, Bénitte, and Richard, 1955; Boeré, 1956 ; Pratt and Collins, 1956) presumably due to migration of potassium from the serum into the cells. On rewarming the reverse takes place, as well as an increase in potassium excretion in the urine. As, however, any operation results in an increased potassium and decreased sodium urinary loss owing to adrenocortical stimulation (Graham, 1954), the changes noted after hypothermia by other workers are therefore probably not specific. These studies have failed to show any increase in potassium excretion due to hypothermia.

It is in the light of the possible complications and danger of hypothermia that the results of the investigation have to be considered.

Increased Myocardial Irritability.-Swann et al. (1953) reported that respiratory acidosis associated with reduced serum potassium increases the incidence of ventricular fibrillation in dogs. Another observation was that the hypothermic myocardium in ventricular fibrillation loses potassium and that injections of potassium, prostigmine, or acetylcholine into the coronary circulation, as well as vagal stimulation, have a marked antifibrillatory effect. Several workers (Scurr and Organe, 1956 ; Swan, 1956 ; Gray, 1957) therefore advocate the use of hyperventilation with the production of a respiratory alkalosis in an endeavour to reduce the incidence of fibrillation and perfusion of the coronary circulation with potassium or prostigmine to defibrillate the resistant cold heart. Although in the present series a slight reduction in serum potassium accompanied a mild acidosis, there was not a single instance of ventricular fibrillation. This confirms the findings of the Liverpool Neurosurgical Unit, where in 180 consecutive craniotomies under hypothermia no cases of fibrillation were recorded (Gray, 1957), and in Toronto (Gunton et al., 1956) where, in only two cases of fibrillation noted, hypotensive agents were used concurrently. Therefore, provided that the pre-operative levels of potassium and bicarbonate are normal, the dangers of in- 
creased myocardial irritability in neurosurgical practice are negligible, even in the absence of hyperventilation, which was not employed.

Hyperelectrolytaemia.-Allott (1957) described several cases of bulbar poliomyelitis showing greatly increased serum sodium and chloride levels, with a greatly reduced urinary output of these ions and retention of urea. A similar biochemical picture has also been described in a number of intracranial lesions, notably tumours and ruptured berry aneurysms, both conditions in the surgical treatment of which hypothermia is increasingly being employed. Recently a patient was seen suffering from a subarachnoid haemorrhage who died from irreversible electrolyte changes, similar to those described by Allott, before an operation could be carried out. Although this rare complication, whose cause is uncertain, has not yet been described in hypothermia, the possibility should not be overlooked, particularly when dehydration and cessation of urinary excretion are present demanding prompt and intensive treatment.

Disturbed Liver Function.-As hypothermia reduces cell metabolism of the whole body, so liver function also is progressively reduced with a lowering of body temperature, glycogenesis, for instance, virtually ceasing below $31^{\circ}$ C. $\left(88^{\circ} \mathrm{F}\right.$.) Fisher, Fedor, Lee, Weitzel, Selker, and Russ (1956) have shown in experiments on dogs that after six hours of hypothermia there is a significant reduction in the glycogen and increase in non-protein-nitrogen content of the liver with some delay before full recovery on re-warming. Other workers have noted increases in the levels of blood sugar (Wynn, 1954) and urea (Talbott, 1941; Ciocatto, Brena, Fava, and Marocco, 1953) during hypothermia, which is in line with our findings. In two of our patients, serial blood' sugar estimations carried out at twohourly intervals during rewarming showed a progressive reduction in the sugar concentration with increasing temperature. This hyperglycaemia, which is constant and unaccompanied by ketosis or glycosuria, is therefore reversible and apparently without effect on the hypothermic patient, though this may not be true of someone who is diabetic, where hypothermia may lead to ketosis with consequently greater danger of myocardial irritability.

There are very few reports in the literature of protein studies during hypothermia and apparently none where electrophoresis was also carried out. Although this series demonstrated no significant changes in the total protein concen- tration, the relatively few electrophoreses so far carried out showed changes in the globulin during hypothermia which were not present when hypothermia was not employed. Further studies are now being carried out.

Brewin, Gould, Nashat, and Neil (1955) have shown in dogs that complete circulatory arrest for 10 minutes at $26^{\circ} \mathrm{C}$. $\left(79^{\circ} \mathrm{F}\right.$.) produces a profound disturbance of galactose removal, with correspondingly severe histological changes due to venous congestion and anoxia. Similar but less severe changes were seen in patients undergoing thoracotomy. This resulted in a progressive increase in lactacidosis during rewarming and jeopardized recovery. It was therefore felt that prevention of visceral congestion would prevent this metabolic upset. This infrequent complication cannot occur in patients undergoing craniotomy, as only local circulatory occlusion is practised. Histological studies in patients in this series who died have demonstrated no abnormalities in the liver.

Acute Pancreatitis.-Smith (1942) described several cases of acute pancreatitis developing in patients following the use of hypothermia. Histological studies revealed an incidence of minor degenerative changes of the pancreas in nearly $10 \%$ of his cases. No definite cause could be put forward, but it was thought to be due to autodigestion, the decrease in enzymatic activity of the pancreas not keeping pace with tissue resistance through relative anoxia from diminished blood flow. Although this complication has not been described elsewhere, pancreatic activity was investigated by estimating the serum amylase. It will be seen from the results that no significant changes were demonstrated; in only one patient did the diastase level reach 170 Somogyi units post-operatively. It may therefore be concluded that pancreatitis is unlikely to become a complication of hypothermia.

Decreased Blood Coagulability. - Various authors, notably Talbott (1941), Cahn (1953), N Deterling et al. (1955), and Gray (1957), have $\underset{\omega}{N}$ reported an increased tendency to bleeding during and following hypothermia, due to an upset of $\varrho$ the clotting mechanism. A number of cases of intractable post-operative wound oozing, some $\stackrel{\oplus}{+}$ fatal, have been described, but as in several of $\underline{T}$ these associated lesions, such as cirrhosis of the $\vec{P}$ liver, were also present, a good cause for incrimi- $\stackrel{\mathbb{D}}{\mathbb{D}}$ nating hypothermia has not been made out. $\stackrel{\mathbb{Q}}{\varrho}$ Nevertheless, as a reduction in the platelet count and prothrombin concentration and an increase in coagulation time have been mentioned as? 
occurring following hypothermia, a series of investigations on these was carried out. As will be seen from Table II, the changes that did occur were negligible and not significant. Clinically no abnormal bleeding was noted either during or after hypothermia. Nevertheless, until there is absolute proof to the contrary, any condition leading to impairment of the clotting mechanism, such as liver damage, should be considered a contraindication to hypothermia.

\section{Conclusions}

These results have shown significant differences in the electrolyte picture. Neurosurgical cases are much less prone to acid-base imbalance, which stimulates ventricular arrhythmia, less likely to develop liver dysfunction and in consequence also less prone to show abnormal bleeding tendencies. Nevertheless, the following tests are worth carrying out: the serum potassium and bicarbonate, before and during hypothermia, as a guide to correcting an acidosis, though the most sensitive measure of myocardial irritability is still the E.C.G., and blood sugar to exclude diabetes. All other biochemical investigations and tests of clotting function of blood are only indicated when complications unassociated with hypothermia are suspected. It will therefore be seen that, as far as can be judged at present, the only danger of hypothermia that can be anticipated by invoking the aid of the laboratory is ventricular arrhythmia, but one can thus also exclude from hypothermia those patients in whom this procedure is contraindicated.

\section{Summary}

Investigations were carried out on 38 patients undergoing craniotomy under hypothermia for the treatment of vascular abnormalities and benign tumours, to demonstrate possible differences in biochemical and haematological findings compared with cardiac surgery and evaluate any screening tests that might be employed to anticipate any of the recognized or theoretical complications of hypothermia.

Significant changes were found in the serum potassium, bicarbonate and protein and blood sugar and urea concentrations, but not in serum sodium, calcium, magnesium, fibrinogen and prothrombin concentrations, coagulation time, and platelet count. These findings were compared with those described in cardiac surgery and it was concluded that neurosurgical cases are much less prone to acid-base imbalance, stimulating ventricular fibrillation, less likely to develop liver damage and in consequence less prone to abnormal bleeding tendencies.

The tests that are worth carrying out are the serum potassium and bicarbonate determinations before hypothermia as a guide to correcting an acidosis and the blood sugar to exclude hyperglycaemia. Other tests are only indicated when complications unassociated with hypothermia are suspected. The only danger of hypothermia that can be anticipated by carrying out the above tests is ventricular arrhythmia, though one can exclude from hypothermia those patients in whom this procedure is contraindicated.

\section{REFERENCES}

Allott, E. N. (1957). Lancet, 1, 246.

Boeré, L. A. (1956). Irish J. med. Sci., No. 369, p. 387.

Brewin, E. G., Gould, R. P., Nashat, F. S., and Neil, E. (1955). Guy's Hosp. Rep., 104, 177.

Nashat, F. S., and Neil, E. (1956). Brit. J. Anaesth., $28,2$.

Cahn, J. (1953). Folia clin. int. (Barcelona), 3, 324.

Churchill-Davidson, H. C. (1955). Brit. J. Anaesth., 27, 313.

Ciocatto, E., Brena, S., Fava, E., and Marocco, F. (1953). Minerva med. (Torino), 1,352 .

Dale, H. H., and Laidlaw, P. P. (1911). J. Path. Bact., 16, 351.

Darmady, E. M., and Davenport, S. G. T. (1954). Haematological Technique, p. 148. Churchill, London.

Deterling, R. A., Jr., Nelson, E., Bhonslay, S., and Howland, W. (1955). A.M.A. Arch. Surg., 70, 87.

Domingo, W. R., and Klyne, W.'(1949). Biochem. J., 45, 400.

Fisher, B., Fedor, E. J., Lee, S. W., Weitzel, W. K., Selker, R., and Russ, C. (1956). Surgery, 40, 862.

Folin, O., and Wu, H. (1920). J. biol. Chem., 41, 367.

Graham, G. (1954). Brit. med. J., 1, 225.

Gray, T. C. (1957). Lancet, 1, 383.

Gunton, R. W., Scott, J. W., Lougheed, W. M., and Botterell, E. H. (1956). Amer. Heart J., 52, 419.

Hiller, A., McIntosh, J. F., and Van Slyke, D. D. (1927). J. clin. Invest., 4, 235.

Jaulmes, C., Delga, J., Bénitte, A., and Richard, S. (1955). C.R. Soc. Biol. (Paris), 149, 1386.

Pratt, G. H., and Collins, V. J. (1956). Surg. Clin. N. Amer., 36, 405.

Scurr, C. F., and Organe, G. S. W. (1956). In British Surgical Practice-Surgical Progress 1956, p. 177. Butterworth, London.

Smith, R. (1942). Lancet, 2, 215.

Somogyi, M. (1941). Arch. intern. Med., 67, 665.

Stone, H. H., Donnelly, C., and Frobese, A. S. (1956). Surg. Gynec. Obstet.,103, 313 .

Swan, H. (1956). Surg. Clin. N. Amer., 36, 1009.

Weavin, I., Holmes, J. H., and Montgomery, V. (1953). Ann. Surg., 138, 360.

Talbott, J.' H. (1941). New Engl. J. Med., 224, 281.

Tisdall, F. F. (1923). J. biol. Chem., 56, 439

Van Slyke, D. D., and Cullen, G. E. (1917). Ibid., 30, 289

Wynn, V. (1954). Lancet, 2, 575. 